\title{
Massive Open Online Course (MOOCs) Acceptance: The Role of Task-Technology Fit (TTF) for Higher Education Sustainability
}

\author{
Ibrahim Youssef Alyoussef
}

check for

updates

Citation: Alyoussef, I.Y. Massive Open Online Course (MOOCs)

Acceptance: The Role of

Task-Technology Fit (TTF) for Higher

Education Sustainability.

Sustainability 2021, 13, 7374. https://

doi.org/10.3390/su13137374

Academic Editors: Waleed

Mugahed Al-Rahmi, Jordi

Colomer Feliu and

Qusay Al-Maatouk

Received: 31 May 2021

Accepted: 28 June 2021

Published: 1 July 2021

Publisher's Note: MDPI stays neutral with regard to jurisdictional claims in published maps and institutional affiliations.

Copyright: (C) 2021 by the author. Licensee MDPI, Basel, Switzerland. This article is an open access article distributed under the terms and conditions of the Creative Commons Attribution (CC BY) license (https:// creativecommons.org/licenses/by/ $4.0 /)$.
Education Technology Department, Faculty of Education, King Faisal University, Al Ahsa 31982, Saudi Arabia; ialyoussef@kfu.edu.sa

\begin{abstract}
The aim of the present study was to narrow the gap in the literature on the adoption of massive open online courses (MOOCs) and the role of task-technology fit (TTF), which influences student satisfaction, academic performance, and the long-term viability (sustainability) of MOOCs in higher education. While researchers have examined MOOC acceptance in a variety of contexts, the role of TTF as a mediating variable in evaluating education sustainability has not been explored using the technology acceptance model (TAM). As a result, the aim of this study was to create a new paradigm by combining two theories: TTF and TAM. Therefore, this study surveyed 277 university students from public universities using the structural equation modeling (SEM) approach to learn about their perceptions toward MOOCs as a method of achieving higher education sustainability. According to the findings, perceived ease of use had a positive impact on perceived enjoyment, perceived usefulness, and social influence, which in turn had a positive impact on task-technology fit and MOOCs use as a method of sustainability in higher education. Task-technology fit also had a positive impact on MOOC use as a method of sustainability. Finally, the role of task-technology fit and MOOCs in educational sustainability had a positive effect on students satisfaction and academic performance. As a result, the use of MOOCs in learning processes should be encouraged in higher education institutions to ensure their long-term viability (sustainability).
\end{abstract}

Keywords: MOOCs; TAM; TTF; sustainability in higher education

\section{Introduction}

Massive open online courses (MOOCs) have triggered public curiosity around the world, attracting a larger population than conventional online education. MOOCs are both free and open to all forms of students [1]. MOOC services such as Coursera, edX, and Udacity advanced quickly in early 2012 by offering online classes. In 2018, nearly 81 million people enrolled in 9400 MOOCs produced by more than 800 higher education institutions, showing the massive increase of MOOCs [2]. Both the number of MOOC students and the number of institutions that offer MOOCs are expected to grow in the future. In standard face-to-face classes, teachers typically encourage learning experiences, while learners in MOOCs are supposed to be responsible for and in control of their own learning [3]. MOOC management and sustainability, on the other hand, is a significant obstacle. Many universities are grappling with ways to prolong the existence of MOOCs by making them self-paced, such as redesigning MOOC tasks to exclude instructor or facilitator interaction. Multiple-choice questions and automatic reviews may be used to substitute for collaborative tasks in this overhaul [4]. Aside from the excitement, there were a slew of obstacles to the long-term viability of MOOCs [5]. The future paths and educational sustainability of MOOCs were perhaps the most closely linked to our work. These courses were effectively completely free and were bootstrapped by venture capital contributions [6], but their potential position in the higher education environment remained unknown. Universities made significant investments to plan output pipelines, create new 
multimedia divisions, procure facilities, and retrain professors to teach MOOCs, among other factors [7]. For the past 30 years, high-quality schooling has been regarded as critical to ensuring our society's long-term viability [8]. The word "sustainability" has been used to describe the ability to satisfy current demands without risking the resources of future generations. Education has been identified as a key enabler for achieving sustainable development on a global level [9]. As a result of the rise in the number of MOOCs, many sustainability educators have been able to change their practice by creating content related to energy and wealth, ethics, environment, and management [10]. The findings about MOOCs are consistent with those of previous studies [11,12], which show that one of the most critical contents of sustainability education is ethics. According to the research by Beltrán et al. [13] on sustainability and MOOCs, the effect of MOOCs is stronger if developers incorporate sustainability topics into the content and inspire students to use them. Therefore, this paper explores how a university-based MOOC has provided the impetus for widespread education on social learning and sustainability. Therefore, this article examines the role of TTF with a TAM model in MOOC device use as a sustainable way to influence students' academic performance. Furthermore, the present study aims to determine whether and how the above considerations influence the use of a MOOC system as a way of influencing student academic performance through two theories (TAM and TTF). As a result, this paper proposes a research framework for integrating the technology acceptance model (TAM) for MOOC system use with the task-technology fit model (TTF) for influencing student academic performance.

\section{Theoretical Model and Hypotheses Development}

The TAM model is widely used for analyzing and defining users' decisions to implement new technologies. As a result, the TAM model was used in this study, which was expanded to include task-technology fit variables. TAM, developed by Davis [14], and the TTF, developed by Goodhue and Thompson [15], both have been at the core of the literature on information system adoption. While the TAM model relies solely on users' attitudes toward using a certain information technology tool based on perceived usefulness and ease of use, the TTF model is based on the concept of ensuring a reasonable fit of capabilities and task conditions, resulting in better performance. By addressing these limitations, combining the two models will provide a clearer understanding of information system use. To maximize explanatory capacity, several experiments have merged the TAM and TTF models [16-19]. Therefore, in the current research, seven influences on TAM and TTF model of MOOCs system usage as sustainability were analyzed as follows: perceived usefulness (PU), perceived ease of use (PEU), perceived enjoyment (PE), social influence (SI), task-technology fit (TTF), MOOC use as sustainability (MUS), student satisfaction (SS), and student academic performance (SAP), see Figure 1.

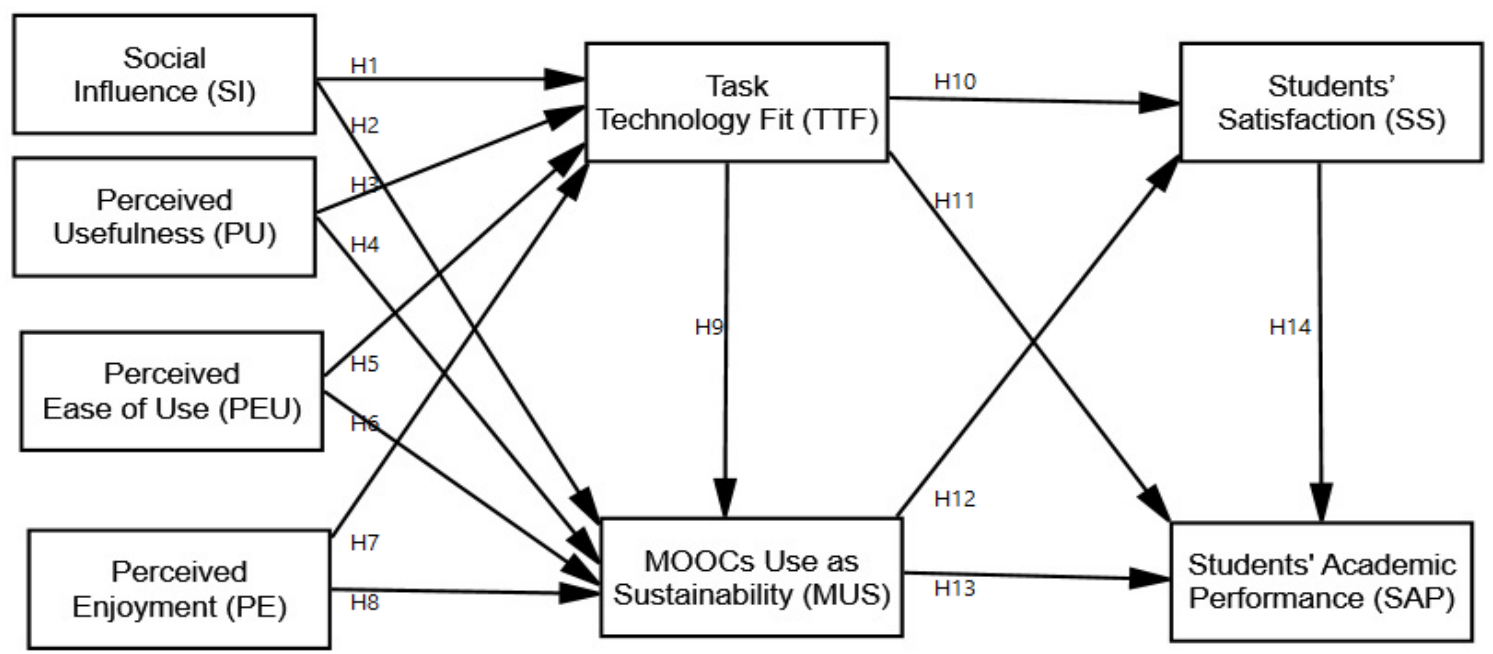

Figure 1. Research Model any Hypotheses. 


\subsection{Social Influence (SI)}

Individuals may follow a technology not because of their own personal convictions, but because of the opinions of others, according to information systems researchers [20]. According to the unified theory of acceptance and use of technology (UTAUT), social influence plays an important role in determining user acceptance of information technology [21]. In our study, social influence is described as the perception that others expressly approve of and encourage a user's engagement in MOOCs [22]. When people see how others use MOOCs and see the advantages of doing so, they are more likely to use MOOCs themselves, potentially increasing both the current and future usage of MOOC technology. Similarly, we expect social influence to include a student's sense of usefulness from others and to play a significant role in influencing attitudes toward MOOC use.

\subsection{Perceived Usefulness (PU)}

The users' subjective evaluation of whether using a specific device can improve job results is reflected in perceived usefulness [23]. The degree to which students believe MOOCs can be a guiding factor for achieving learning goals is the perceived usefulness of MOOCs. Furthermore, according to several observational research studies, perceived usefulness mediates the impact of perceived ease of use on behavioral intention. For example, it has been stated in the MOOC literature that perceived usefulness has a substantial impact on the decision to continue using MOOCs [24-27].

\subsection{Perceived Ease of Use (PEU)}

The perceived ease of use of MOOCs can be described as the degree to which students believe that using MOOCs would be painless [18]. The simplicity with which MOOCs can be used to learn new skills is an indication of perceived ease of use. Previous research has shown that perceived ease of use has a favorable impact on users' attitudes and the perceived utility of systems [28]. In MOOCs, perceived ease of use is critical for perceived usefulness and attitudes toward MOOCs and big data [29-31]. Similarly, perceived ease of use can influence the acceptance of MOOCs either directly, or indirectly through their usefulness.

\subsection{Perceived Enjoyment (PE)}

Mulik et al. [32] define perceived enjoyment, which is a component of intrinsic motivation, as the degree to which a person believes using a MOOC is enjoyable. While one study found no connection between perceived enjoyment and MOOC acceptance [32], other studies $[26,33]$ found a positive effect of perceived enjoyment on the intention to use MOOCs in the future. This construct is more accurately defined as perceived enjoyment, which is a strong indicator of a student's intentions to use MOOCs in higher education [34,35].

\subsection{Task-Technology-Fit (TTF)}

TTF is now being studied and extended to a variety of information systems [36]. Although TTF has been studied in a variety of contexts, no study has been done in MOOCs. It is still unknown whether or not a successful task-technology fit can influence a user's adoption of MOOCs, and if so, how well it will influence a user's adoption [18]. The TTF model does not discuss social variables in the sense of MOOCs, which may hinder its ability to forecast social technologies. The constraint can be solved by including social encouragement, which takes into account perceived usefulness, ease of use, enjoyment, and social influence $[18,37,38]$.

\subsection{MOOCs Use as Sustainability (MUS)}

MOOCs are being used to improve both teaching and learning. On the one hand, MOOCs enable teachers to meet a vast number of students all over the world [39]. MOOCs, on the other hand, enable students to receive free and open education from some of the world's most prestigious universities, which have a far wider audience than conventional 
online education. MOOC students are often groups of people that have similar values [39]. MOOCs are now a highly debated emerging subject in education, according to recent research. The most critical characteristic of a MOOC is that it is open. Free access, adaptation, remixing, sharing, and collaboration as sustainability are five of the virtues of accessibility that are central components of MOOCs [40]. Some scholars have proposed that MOOCs cater to students who are self-motivated and believe that MOOCs are helpful at the individual learning stage [41].

\subsection{Students Satisfaction (SS)}

Student satisfaction measures when students succeed in their studies and are satisfied with their overall experience [42,43]. Two variables are considered crucial and significant in terms of consumer acceptance of such technology and satisfaction: perceived usefulness and perceived ease of use. These variables are important because they can predict user satisfaction with a certain website or device $[14,44]$. According to studies, the level of user enjoyment plays a significant role in forecasting the performance of any technology. Based on this, $[45,46]$ proposed a method for improving students' learning and satisfaction in MOOCs by adopting digital forms of interaction.

\subsection{Students' Academic Performance (SAP)}

Students' academic performance has an effect on education sustainability as a demonstration of a student's level of maturity and mastery of a subject by the execution of various measures of competence in a given area [47-49]. The aim of this research is to determine students' academic success based on the online traces they leave when taking a MOOC course. To allow more reliable predictions for student and performance, Ye and Biswas [50] used expanded standard features for higher granularity with MOOC analysis. The achievement of educational goals in terms of knowledge development and capability growth is measured by students' academic performance in terms of education sustainability [51].

\section{Research Methodology}

In this study, a new model was developed to explore the importance of independent variables in the use of MOOCs, as well as the role of TTF in higher education sustainability. Therefore, the distributed questionnaire survey involved using the MOOC system as a quantitative approach for participants. Individuals that used a MOOC were used as a filtering criterion for the survey. The sample size for the analysis was determined using Roscoe's Rule of Thumb [52]. As a result, multiplying 10 by 26 items provided a sufficient sample size of 260 participants for this study. Therefore, 277 undergraduate students participated in this study, and the structural equation modeling (SEM) approach to learn about their perceptions of MOOCs as a method of achieving their higher education goals. The study used a questionnaire form with a five-point scale that was given to a large group of population and included 26 items and eight variables. The 5-point Likert scale used in this analysis to assess students' ratings of various items included the options "strongly disagree (1), disagree (2), unsure (3), agree (4), strongly agree (5)." For the purposes of research, we used structural equation modeling (SEM, Smart-PLS), as recommended by [53].

\section{Model of Measurement}

The instruments used to measure the constructs were created by adapting and adopting widely used validated scales from previous studies. The sample questionnaire was divided into two sections: Basic demographic management (gender, age, educational level, and specialization), and questionnaire items measuring perceived usefulness, perceived ease of use, perceived enjoyment, and using MOOCs were adapted from [23], social influence was adapted from [54], task-technology fit was adapted from [55], students' satisfaction was adapted from [56], and students' academic performance was adapted from [47]. 


\section{Analysis and Results}

The Cronbach's alpha reliability coefficient was found to be 0.881 , meaning that the variables that influenced MOOCs' use as a means of higher education sustainability, in turn, influenced students' satisfaction and academic performance. Particpant gender, age, degree of education, and specialty were used to categorize participant background information. In terms of gender, $168(60.6 \%)$ were male, $109(39.4 \%)$ were female, $183(66.1 \%)$ were between the ages of 18 and 21, $57(20.6 \%)$ were between the ages of 22 and 25 , and $37(13.3 \%)$ were between the ages of 26 and 29. There were $213(76.9 \%)$ undergraduate students and 64 $(23.1 \%)$ postgraduate students at this level of education. In contrast to the demographic factors of specialization, $59(21.3 \%)$ of respondents were from social science, $56(20.2 \%)$ of respondents were from engineering, and $162(58.5 \%)$ of respondents were from science and technology. Discriminant validity was assessed using three criteria: variable indices must be less than 0.70 , each construct's average variance extracted (AVE) must be equal to or greater than 0.5 , and the AVE square root of each construct must be greater than the inter-construct correlations (IC) for a factor, according to [53]. Aside from the above variables, build variable analysis results with factor loadings of 0.70 or higher (Cronbach's alpha 0.70 and composite reliability 0.70 ) were considered acceptable [53].

\subsection{Measurement Construct Validity}

The degree to which individual objects determine the definition for which they were developed [35] is referred to as construct validity. This was determined by a thorough examination of items previously tested in the literature. Table 1 shows the items and their loadings that must be loaded into the construct they were created to measure [53].

Table 1. Loadings and cross-loadings of items.

\begin{tabular}{|c|c|c|c|c|c|c|c|c|c|}
\hline Factors & Items & MUS & PE & PEU & PU & SAP & SI & SS & TTF \\
\hline \multirow{3}{*}{ MOOCs Use As Sustainability } & MUS1 & 0.872 & 0.481 & 0.471 & 0.501 & 0.503 & 0.551 & 0.536 & 0.449 \\
\hline & MUS2 & 0.863 & 0.522 & 0.483 & 0.528 & 0.501 & 0.506 & 0.571 & 0.441 \\
\hline & MUS3 & 0.843 & 0.534 & 0.470 & 0.558 & 0.448 & 0.509 & 0.543 & 0.443 \\
\hline \multirow{3}{*}{ Perceived Enjoyment } & PE1 & 0.561 & 0.894 & 0.533 & 0.504 & 0.588 & 0.533 & 0.727 & 0.553 \\
\hline & PE2 & 0.585 & 0.917 & 0.560 & 0.554 & 0.610 & 0.578 & 0.784 & 0.620 \\
\hline & PE3 & 0.453 & 0.881 & 0.515 & 0.449 & 0.573 & 0.471 & 0.693 & 0.609 \\
\hline \multirow{3}{*}{ Perceived Ease of Use } & PEU1 & 0.473 & 0.540 & 0.828 & 0.617 & 0.399 & 0.496 & 0.527 & 0.405 \\
\hline & PEU2 & 0.415 & 0.444 & 0.827 & 0.446 & 0.437 & 0.479 & 0.482 & 0.484 \\
\hline & PEU3 & 0.483 & 0.502 & 0.828 & 0.487 & 0.479 & 0.446 & 0.503 & 0.417 \\
\hline \multirow{3}{*}{ Perceived Usefulness } & PU1 & 0.576 & 0.494 & 0.568 & 0.891 & 0.401 & 0.504 & 0.513 & 0.405 \\
\hline & PU2 & 0.534 & 0.487 & 0.518 & 0.917 & 0.422 & 0.535 & 0.532 & 0.425 \\
\hline & PU3 & 0.544 & 0.528 & 0.589 & 0.880 & 0.436 & 0.535 & 0.548 & 0.444 \\
\hline \multirow{4}{*}{ Students' Academic Performance } & SAP1 & 0.483 & 0.552 & 0.383 & 0.368 & 0.813 & 0.411 & 0.538 & 0.581 \\
\hline & SAP2 & 0.473 & 0.557 & 0.399 & 0.376 & 0.862 & 0.443 & 0.566 & 0.636 \\
\hline & SAP3 & 0.464 & 0.527 & 0.468 & 0.364 & 0.818 & 0.440 & 0.556 & 0.586 \\
\hline & SAP4 & 0.447 & 0.543 & 0.502 & 0.441 & 0.816 & 0.452 & 0.550 & 0.660 \\
\hline \multirow{3}{*}{ Social Influence } & SI1 & 0.437 & 0.377 & 0.391 & 0.356 & 0.365 & 0.767 & 0.429 & 0.469 \\
\hline & SI2 & 0.558 & 0.593 & 0.559 & 0.586 & 0.509 & 0.911 & 0.616 & 0.566 \\
\hline & SI3 & 0.573 & 0.541 & 0.520 & 0.556 & 0.483 & 0.910 & 0.572 & 0.515 \\
\hline
\end{tabular}


Table 1. Cont.

\begin{tabular}{|c|c|c|c|c|c|c|c|c|c|}
\hline Factors & Items & MUS & PE & PEU & PU & SAP & SI & SS & TTF \\
\hline \multirow{4}{*}{ Students' Satisfaction } & SS1 & 0.612 & 0.694 & 0.525 & 0.568 & 0.567 & 0.539 & 0.831 & 0.547 \\
\hline & SS2 & 0.559 & 0.638 & 0.540 & 0.511 & 0.579 & 0.555 & 0.862 & 0.580 \\
\hline & SS3 & 0.492 & 0.726 & 0.520 & 0.435 & 0.561 & 0.520 & 0.873 & 0.627 \\
\hline & SS4 & 0.546 & 0.770 & 0.516 & 0.530 & 0.595 & 0.555 & 0.884 & 0.622 \\
\hline \multirow{3}{*}{ Task-Technology-Fit } & TTF1 & 0.424 & 0.481 & 0.422 & 0.335 & 0.584 & 0.454 & 0.519 & 0.834 \\
\hline & TTF2 & 0.435 & 0.586 & 0.460 & 0.408 & 0.661 & 0.522 & 0.643 & 0.884 \\
\hline & TTF3 & 0.481 & 0.640 & 0.482 & 0.478 & 0.685 & 0.571 & 0.618 & 0.879 \\
\hline
\end{tabular}

\subsection{Measurement Validity That Is Convergent}

The factor loadings of 26 items were deemed acceptable because they were greater than 0.70 and their composite reliability ranged from 0.924 to 0.867 . Cronbach's alpha coefficient values ranged from 0.885 to 0.770 , suggesting satisfactory performance. The AVE values varied between 0.806 and 0.685 . Hair et al. [53] mentions the findings of the confirmatory factor analysis (CFA), as shown in Table 2.

Table 2. Factor loadings and confirmatory factor analysis results.

\begin{tabular}{|c|c|c|c|c|c|c|}
\hline Factors & Items & $\begin{array}{l}\text { Factor } \\
\text { Loading }\end{array}$ & $\begin{array}{l}\text { Composite } \\
\text { Reliability }\end{array}$ & $\begin{array}{c}\text { Cronbachs } \\
\text { Alpha }\end{array}$ & AVE & R Square \\
\hline \multirow{3}{*}{ MOOCs Use As Sustainability } & MUS1 & 0.872 & 0.894 & 0.823 & 0.738 & 0.518 \\
\hline & MUS2 & 0.863 & & & & \\
\hline & MUS3 & 0.843 & & & & \\
\hline \multirow{3}{*}{ Perceived Enjoyment } & PE1 & 0.894 & 0.925 & 0.879 & 0.806 & \\
\hline & PE2 & 0.917 & & & & \\
\hline & PE3 & 0.881 & & & & \\
\hline \multirow{3}{*}{ Perceived Ease of Use } & PEU1 & 0.828 & 0.867 & 0.770 & 0.685 & \\
\hline & PEU2 & 0.827 & & & & \\
\hline & PEU3 & 0.828 & & & & \\
\hline \multirow{3}{*}{ Perceived Usefulness } & PU1 & 0.891 & 0.924 & 0.877 & 0.803 & \\
\hline & PU2 & 0.917 & & & & \\
\hline & PU3 & 0.880 & & & & \\
\hline \multirow{4}{*}{ Students' Academic Performance } & SAP1 & 0.813 & 0.897 & 0.847 & 0.685 & 0.616 \\
\hline & SAP2 & 0.862 & & & & \\
\hline & SAP3 & 0.818 & & & & \\
\hline & SAP4 & 0.816 & & & & \\
\hline \multirow{3}{*}{ Social Influence } & SI1 & 0.767 & 0.899 & 0.830 & 0.749 & \\
\hline & SI2 & 0.911 & & & & \\
\hline & $\mathrm{SI} 3$ & 0.910 & & & & \\
\hline \multirow{4}{*}{ Students' Satisfaction } & SS1 & 0.831 & 0.921 & 0.885 & 0.744 & 0.584 \\
\hline & SS2 & 0.862 & & & & \\
\hline & SS3 & 0.873 & & & & \\
\hline & SS4 & 0.884 & & & & \\
\hline \multirow{3}{*}{ Task-Technology-Fit } & TTF1 & 0.834 & 0.900 & 0.834 & 0.750 & 0.511 \\
\hline & TTF2 & 0.884 & & & & \\
\hline & TTF3 & 0.879 & & & & \\
\hline
\end{tabular}




\subsection{Measurement Validity That Is Convergent}

Discriminant validity refers to the differences between the collection of concepts and their metrics. Both constructs' discriminant validity was confirmed with values greater than 0.50 and significant at $p=0.001$, as expected by the analysis [53]. According to [53], the AVE square root shared by objects in a single construct should be smaller than the correlations between items in the two constructs, as seen in Table 3.

Table 3. Discriminant validity.

\begin{tabular}{|c|c|c|c|c|c|c|c|c|}
\hline Factors & MUS & PEU & PE & PU & SI & SAP & SS & TTF \\
\hline MOOCs Use as Sustainability & 0.887 & & & & & & & \\
\hline Perceived Ease of Use & 0.552 & 0.900 & & & & & & \\
\hline Perceived Enjoyment & 0.596 & 0.598 & 0.893 & & & & & \\
\hline Perceived Usefulness & 0.615 & 0.624 & 0.562 & 0.890 & & & & \\
\hline Social Influence & 0.607 & 0.572 & 0.590 & 0.586 & 0.901 & & & \\
\hline Students' Academic Performance & 0.564 & 0.530 & 0.658 & 0.469 & 0.527 & 0.917 & & \\
\hline Students' Satisfaction & 0.640 & 0.609 & 0.520 & 0.593 & 0.629 & 0.667 & 0.897 & \\
\hline Task-Technology-Fit & 0.517 & 0.526 & 0.662 & 0.474 & 0.599 & 0.745 & 0.689 & 0.931 \\
\hline
\end{tabular}

\subsection{The Analysis of the Structural Model}

To validate the research hypotheses and examine the built relationships, Smart PLS 2.0 was used. The hypothesis is seen in Figure 1, the path coefficient findings are seen in Figure 2, and the path coefficient (T-values) findings are seen in Figure 3.

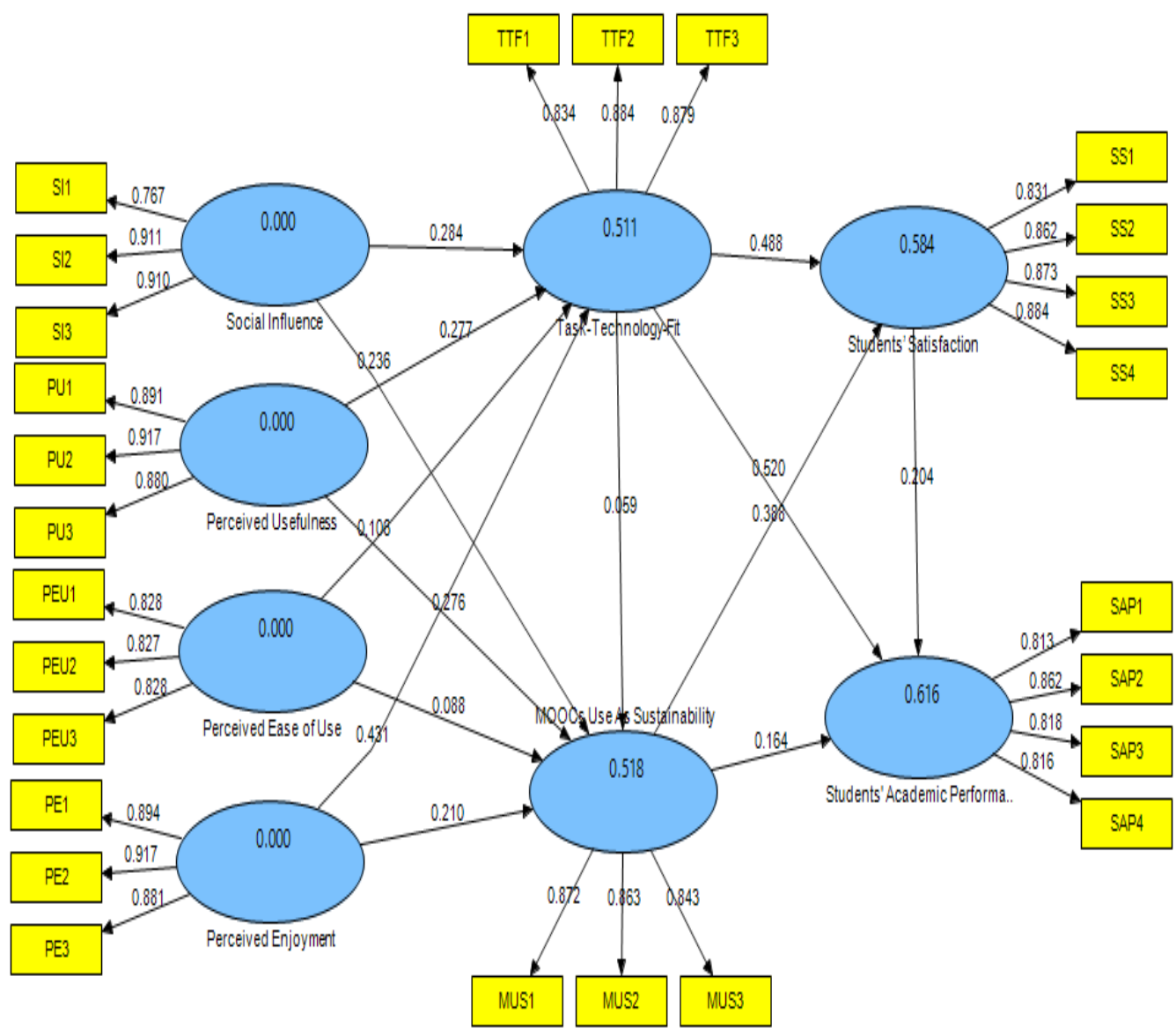

Figure 2. Path coefficient findings. 


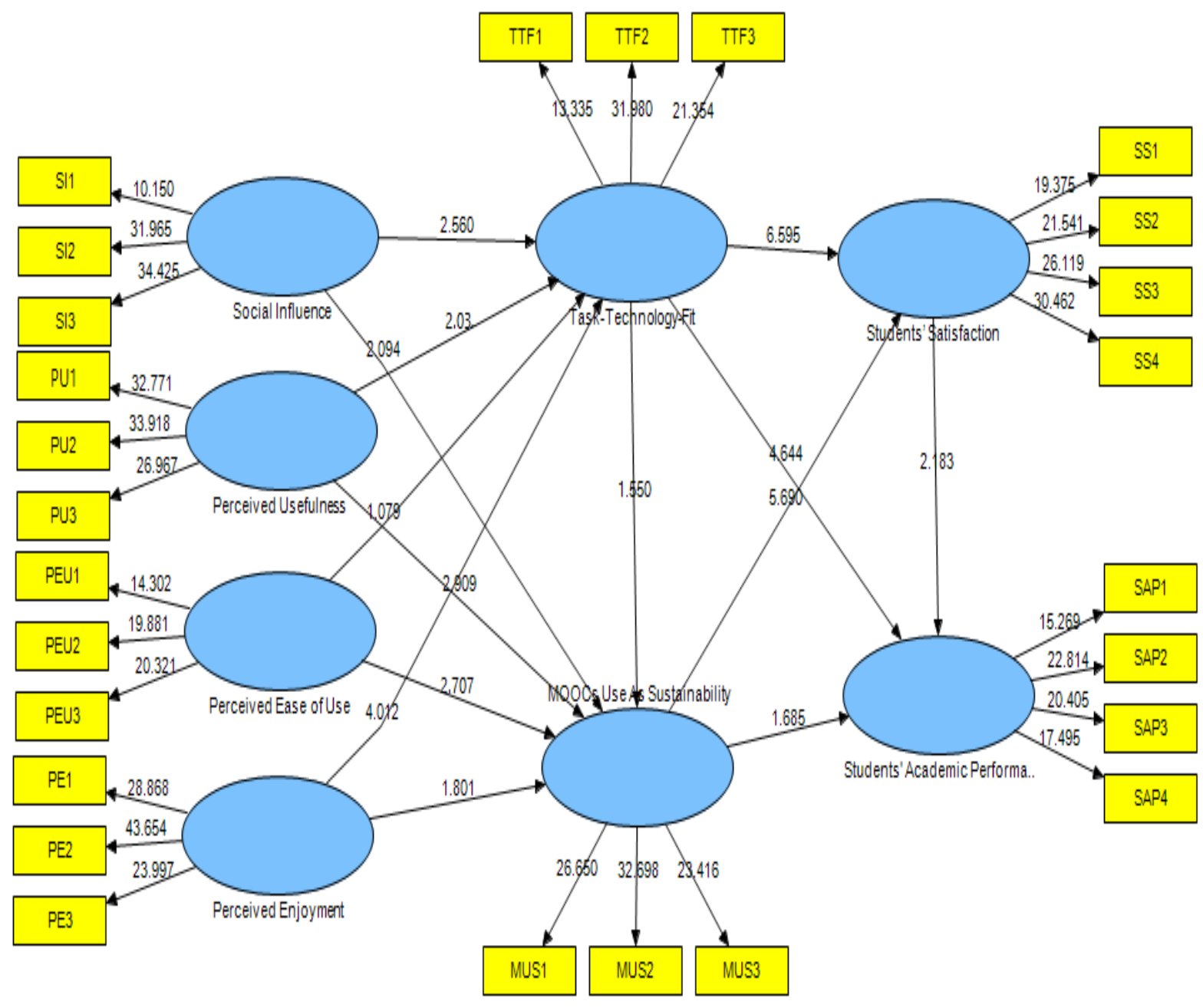

Figure 3. Path T-value findings.

Table 4 shows the study's findings, highlighting all relationships. The relationship between social influence and task-technology-fit $(\mathrm{H} 1)(\beta=0.284, \mathrm{SE}=0.111, \mathrm{t}=2.560)$ was positive. Likewise, and the relationship between social influence and MOOC use as sustainability $(\mathrm{H} 2)(\beta=0.236, \mathrm{SE}=0.113, \mathrm{t}=2.094)$ was positive. The relationship between perceived usefulness and task-technology fit $(\mathrm{H} 3)(\beta=0.277, \mathrm{SE}=0.116, \mathrm{t}=2.034)$ was positive. The relationship between perceived usefulness and MOOC use as sustainability (H4) $(\beta=0.276, \mathrm{SE}=0.095, \mathrm{t}=2.909)$ was positive. The relationship between perceived ease of use and task-technology fit (H5) $(\beta=0.106, \mathrm{SE}=0.098, \mathrm{t}=1.079)$ was positive. The relationship between perceived ease of use and MOOC use as sustainability $(\mathrm{H} 6)(\beta=0.088$, $\mathrm{SE}=0.125, \mathrm{t}=2.707$ ) was positive. The relationship between perceived enjoyment and task-technology fit $(\mathrm{H7})(\beta=0.431, \mathrm{SE}=0.108, \mathrm{t}=4.012)$ was positive. The relationship between perceived enjoyment and MOOC use as sustainability $(\mathrm{H} 8)(\beta=0.210, \mathrm{SE}=0.117$, $t=1.801)$ was positive. The relationship between MOOC use as sustainability and student academic performance $(\mathrm{H} 9)(\beta=0.164, \mathrm{SE}=0.097, \mathrm{t}=1.685)$ was positive. The relationship between MOOC use as sustainability and student satisfaction $(\mathrm{H} 10)(\beta=0.388, \mathrm{SE}=0.068$, $t=5.690)$ was positive. The relationship between task-technology fit and MOOC use as sustainability $(\mathrm{H} 11)(\beta=0.059, \mathrm{SE}=0.108, \mathrm{t}=1.550)$ was positive. The relationship between task-technology fit and student satisfaction $(\mathrm{H} 12)(\beta=0.488, \mathrm{SE}=6.595, \mathrm{t}=1.550)$ was positive. The relationship between task-technology fit and student academic performance (H13) $(\beta=0.520, \mathrm{SE}=0.112, \mathrm{t}=4.644)$ was positive. Finally, the relationship between student satisfaction and student academic performance $(\mathrm{H} 14)(\beta=0.204, \mathrm{SE}=0.094$, $\mathrm{t}=2.183$ ) was positive. 
Table 4. Hypothesis testing.

\begin{tabular}{|c|c|c|c|c|}
\hline Path of Hypotheses & Path Coefficient & Standard Error & T-Values & Results \\
\hline Social Influence > Task-Technology-Fit (H1) & 0.284 & 0.111 & 2.560 & Positive \\
\hline Social Influence > MOOCs Use As Sustainability (H2) & 0.236 & 0.113 & 2.094 & Positive \\
\hline Perceived Usefulness > Task-Technology-Fit (H3) & 0.277 & 0.116 & 2.034 & Positive \\
\hline $\begin{array}{c}\text { Perceived Usefulness > MOOCs Use As } \\
\text { Sustainability (H4) }\end{array}$ & 0.276 & 0.095 & 2.909 & Positive \\
\hline Perceived Ease of Use > Task-Technology-Fit (H5) & 0.106 & 0.098 & 1.079 & Positive \\
\hline $\begin{array}{c}\text { Perceived Ease of Use > MOOCs Use As } \\
\text { Sustainability (H6) }\end{array}$ & 0.088 & 0.125 & 2.707 & Positive \\
\hline Perceived Enjoyment > Task-Technology-Fit (H7) & 0.431 & 0.108 & 4.012 & Positive \\
\hline $\begin{array}{l}\text { Perceived Enjoyment > MOOCs Use As } \\
\text { Sustainability (H8) }\end{array}$ & 0.210 & 0.117 & 1.801 & Positive \\
\hline $\begin{array}{c}\text { MOOCs Use As Sustainability > Students' Academic } \\
\text { Performance (H9) }\end{array}$ & 0.164 & 0.097 & 1.685 & Positive \\
\hline $\begin{array}{c}\text { MOOCs Use As Sustainability > Students' } \\
\text { Satisfaction (H10) }\end{array}$ & 0.388 & 0.068 & 5.690 & Positive \\
\hline $\begin{array}{l}\text { Task-Technology-Fit > MOOCs Use As } \\
\text { Sustainability (H11) }\end{array}$ & 0.059 & 0.108 & 1.550 & Positive \\
\hline Task-Technology-Fit > Students' Satisfaction (H12) & 0.488 & 0.074 & 6.595 & Positive \\
\hline $\begin{array}{c}\text { Task-Technology-Fit > Students' Academic } \\
\text { Performance (H13) }\end{array}$ & 0.520 & 0.112 & 4.644 & Positive \\
\hline $\begin{array}{c}\text { Students' Satisfaction > Students' Academic } \\
\text { Performance (H14) }\end{array}$ & 0.204 & 0.094 & 2.183 & Positive \\
\hline
\end{tabular}

\section{Discussion and Implications}

In terms of theory development, this research aims to combine TAM, the TTF model, social impact, and the use of MOOCs as a sustainable means of influencing student satisfaction and academic performance. This is consistent with a survey that gathered data from participants around a wide variety of courses, regardless of their college qualifications or which sites sell their MOOCs [18]. The empirical findings provide substantial evidence for 14 hypotheses. For each hypothesis, we provide the following insights into TAM, the TTF model, social influence, and MOOC use as sustainability to influence student satisfaction and academic performance. The results of the research strongly support the social influence factor, confirming hypotheses numbers one and two, showing that social influence has a positive effect on MOOC use as sustainable educational approach alongside task-technology fit. While the MOOC system is useful and suitable (fit), increased social influence leads to increased use of the MOOC system as a sustainable educational approach, and therefore the technology is fit. A number of studies have identified the importance of social influence in the field of MOOC system use for learning. As a measure, the findings of this study confirm previous findings $[18,57,58]$. Similarly, the results of the research strongly support the perceived usefulness factor, confirming hypotheses number three and four, showing that perceived usefulness has a positive effect on MOOC use as sustainability education approach and task-technology fit. The MOOCs system is useful and suitable (fit), in the sense that increased perceived usefulness leads to increased use of the MOOC system as a sustainable educational approach, and therefore the technology is fit. A number of studies have identified the importance of perceived usefulness in the field of MOOC system use for learning. As a measure, the findings of this study confirm previous findings [59-63]. Additionally, the results of the research strongly support the perceived ease of use factor, confirming hypotheses numbers five and six, showing that perceived ease of use has a positive effect on MOOC use as sustainability education approach 
and their task-technology fit. Given that the MOOC system is easy, useful and suitable (fit), increased perceived ease of use leads to increased use of the MOOC system as a sustainability education approach, and therefore the technology is fit. A number of studies have identified the importance of perceived ease of use in the field of MOOC system use for learning. As a measure, the findings of this study confirm previous findings [64-67]. Non-registered students from anywhere around the world can take courses as non-credit courses via MOOCs [19]. Students enrolled in these courses (MOOCs) are not obliged to pay any tuition, but will be charged a nominal price to receive a certificate of completion from the institutions, as is the case with other some university offerings [26]. Positive attitudes about technology-assisted learning can affect students' inclinations to continue studying [18]. An examination of the literature indicates that MOOCs are well-received by students and teachers as a means towards lifetime learning $[30,39,40]$. Massive open online courses (MOOCs) represent the most recent stage in distance education at the outset of a teaching revolution, and attitudes regarding MOOCs and perceived behavioral control were important predictors of intentions to utilize them [41,50]. Massive open online courses (MOOCs) are becoming more popular throughout the world. Teachers' behavioral intention to embrace MOOCs was helped by performance anticipation, social influence, enabling circumstances, and price value [58]. Furthermore, student satisfaction with MOOC courses was positively influenced by perceived ease of use and perceived utility [59]. Massive open online courses (MOOCs) are quickly becoming the new trend in higher education, and thus, student acceptance is seen as a critical factor in MOOC performance [62,64]. Moreover, the results of the research strongly support the perceived enjoyment factor, confirming hypotheses number seven and eight, showing that perceived enjoyment has a positive effect on MOOCs use as sustainability education approach and task-technology fit. The MOOCs system is enjoyable, useful and suitable (fit), and increased perceived enjoyment leads to increased use of the MOOC system as a sustainability education approach, and therefore the technology is fit. A number of studies have identified the importance of perceived enjoyment in the field of MOOC system use for learning. As a measure, the findings of this study confirm previous findings [68-70]. Furthermore, the results of the research strongly support the task-technology fit factor, confirming hypotheses numbers nine, ten, and eleven, showing that task-technology fit has a positive effect on MOOC use in sustainability education, student satisfaction, and student academic performance. Given that the MOOC system is enjoyable, easy, useful and suitable (fit); increased task-technology fit leads to increased use of the MOOC system as a sustainability education approach, and therefore the technology is, in turn, fit to effect student satisfaction and academic performance. A number of studies have identified the importance of task-technology fit in the field of MOOC system use for learning. As a measure, the findings of this study confirm previous findings [64,71-73]. Additionally, the results of the research strongly support MOOC use as a sustainability education approach factor, confirming hypotheses numbers twelve and thirteen, showing that MOOC use for sustainability has a positive effect on student satisfaction and student academic performance. The MOOCs system is enjoyable, easy, useful and suitable (fit), and so increased MOOC use for sustainability leads to increased student satisfaction and academic performance. A number of studies have identified the importance of MOOCs system use for sustainability education. As a measure, the findings of this study confirm previous findings $[59,69,74]$. The results of the research strongly support the student satisfaction factor, confirming hypothesis number fourteen, showing that student satisfaction has a positive effect on student academic performance. When the MOOCs system is enjoyable, easy, useful, suitable (fit), and the students satisfied; increased student satisfaction leads to the MOOC system to be uses for sustainability and to effect student academic performance. A number of studies have identified the significance of student satisfaction to use of the MOOCs system as a sustainability education approach. As a measure, the findings of this study confirm previous findings [27,42,62,75,76]. According to [77], the majority of e-tutoring users felt that online sources for learning English offer greater convenience and are more effective than no internet resources. Overall, the results 
also demonstrate that performance expectations, effort expectancy, and social influence have positive effects on behavior intentions and facilitating conditions, and that behavioral intentions also have positive effects on use behavior [78]. Therefore, the results of this study have important consequences for MOOC professionals who want to prepare carefully and use effective strategies to increase student satisfaction and academic performance. The use of MOOCs as a long-term way of affecting student satisfaction and academic performance is considered in this analysis as an independent variable correlated with the TAM and TTF. The findings of this study have helped to develop a research model focused on the role of task-technology fit (TTF) as a source of educational sustainability in higher education, which considers enhanced awareness of how to use MOOCs as a source of educational sustainability. Perceived usefulness, perceived ease of use, perceived enjoyment, social influence, task-technology fit, MOOC use as sustainability, student satisfaction, and student academic performance are all determinant TTF and TAM variables in the research model. As a result, this study determines that the TTF and TAM variables have the greatest effect on student satisfaction and academic performance when MOOCs are used as a sustainability education strategy. Therefore, the current study adds to the existing literature in three significant as following:

- $\quad$ First, we build on previous work on MOOCs by stressing the role of task-technology fit (TTF) as a factor in higher education sustainability. Our findings show that MOOCs may have a sustainability effect on student satisfaction and academic performance.

- Second, this study emphasized the importance of combining perceived usefulness, perceived ease of use, perceived enjoyment, and social influence when they contributes to task-technology fit and MOOC use as a sustainability strategy in higher education.

- Finally, our model offers an integrated approach to understanding the role of tasktechnology fit (TTF) as a sustainability factor in higher education, which has previously been studied primarily from the viewpoint of technology acceptance.

\section{Conclusions and Future Works}

This study adds to the theory by applying the TAM model and examining the role of task-technology fit (TTF) in higher education sustainability. The model also establishes 14 hypotheses for measuring how MOOCs use sustainability as a means of influencing student satisfaction and academic performance. In conclusion, the results of this study make important contributions to the development of a new paradigm for using MOOCs as a form of higher education on sustainability. The model established in this article adds to the current literature on MOOC adoption and may encourage institutions and MOOC designers to create effective MOOCs that incorporate sustainability. Future research will focus on the role of faculty in the adoption of MOOCs as a long-term educational solution. As a result, more future research into the relationships between e-learning system complexity is necessary, as is research into the ties between MOOC systems and other educational technology systems. In addition, the roles of observability and trialability in MOOCs should be investigated, especially in terms of adaptation and sustainability in developing-country higher education.

Funding: This research was funded by Deanship of Scientific Research at King Faisal University under Nasher Track 2021 (Grant No. 216109).

Institutional Review Board Statement: Not applicable.

Informed Consent Statement: Not applicable.

Data Availability Statement: Not applicable.

Acknowledgments: The author acknowledges the Deanship of Scientific Research at King Faisal University for the financial support under Nasher Track 2021 (Grant No. 216109).

Conflicts of Interest: The authors declare no conflict of interest. 


\section{References}

1. Voss, B.D. Massive Open Online Courses (MOOCs): A Primer for University and College Board Members; AGB Association of Governing Boards of Universities and Colleges: Washington, DC, USA, 2013.

2. Shah, D. By the Numbers: MOOCS in 2017. Available online: https://www.class-central.com/report/mooc-stats-2017/ (accessed on 18 January 2019).

3. Kizilcec, R.F.; Pérez-Sanagustín, M.; Maldonado, J.J. Self-regulated learning strategies predict learner behavior and goal attainment in Massive Open Online Courses. Comput. Educ. 2017, 104, 18-33. [CrossRef]

4. Rodriguez, B.C.P.; Nieto, M.C.R. How to Run a Massive Open Online Course Once the Funding is Over. In European MOOCs Stakeholders Summit; Springer: Berlin/Heidelberg, Germany, 2019; pp. 156-161.

5. Fischer, G. Beyond hype and underestimation: Identifying research challenges for the future of MOOCs. Distance Educ. 2014, 35, 149-158. [CrossRef]

6. Finkle, T.A.; Masters, E. Do MOOCs Pose a Threat to Higher Education? Res. High. Educ. J. 2014, 26, 10.

7. Hollands, F.M.; Tirthali, D. Why Do Institutions Offer MOOCs? Online Learn. 2014, 18, n3. [CrossRef]

8. Alsina, Á.; Mulà, I. Advancing towards a transformational professional competence model through reflective learning and sustainability: The case of mathematics teacher education. Sustainability 2019, 11, 4039. [CrossRef]

9. Calvo, S.; Lyon, F.; Morales, A.; Wade, J. Educating at scale for sustainable development and social enterprise growth: The impact of online learning and a massive open online course (MOOC). Sustainability 2020, 12, 3247. [CrossRef]

10. Zhan, Z.; Fong, P.S.; Mei, H.; Chang, X.; Liang, T.; Ma, Z. Sustainability education in massive open online courses: A content analysis approach. Sustainability 2015, 7, 2274-2300. [CrossRef]

11. Dirk, M.; Jeremy, M. Corporate Social Responsibility Education in Europe. J. Bus. Ethics 2004, 54, 323-337.

12. Wu, Y.-C.J.; Huang, S.; Kuo, L.; Wu, W.H. Management Education for Sustainability: A Web-Based Content Analysis; Academy of Management Learning \& Education: Briarcliff Manor, NY, USA, 2010; Volume 9, pp. 520-531.

13. Beltrán Hernández de Galindo, M.D.J.; Romero-Rodríguez, L.M.; Ramirez Montoya, M.S. Entrepreneurship competencies in energy sustainability MOOCs. J. Entrep. Emerg. Econ. 2019, 11, 598-616. [CrossRef]

14. Davis, F.D. Perceived usefulness, perceived ease of use, and user acceptance of information technology. Mis. Q. 1989, 13, 319-340. [CrossRef]

15. Goodhue, D.L.; Thompson, R.L. Task-technology and individual performance. Mis. Q. 1995, 19, 213-236. [CrossRef]

16. Närman, P.; Holm, H.; Höök, D.; Honeth, N.; Johnson, P. Using enterprise architecture and technology adoption models to predict application usage. J. Syst. Softw. 2012, 85, 1953-1967. [CrossRef]

17. Lee, D.Y.; Lehto, M.R. User Acceptance of YouTube for Procedural Learning: An Extension of the Technology Acceptance Model. Comput. Educ. 2013, 61, 193-208. [CrossRef]

18. Wu, B.; Chen, X. Continuance intention to use MOOCs: Integrating the technology acceptance model (TAM) and task technology (TTF) model. Comput. Hum. Behav. 2017, 67, 221-232. [CrossRef]

19. Al-Rahmi, W.M.; Aldraiweesh, A.; Yahaya, N.; Kamin, Y.B. Massive open online courses (MOOCS): Systematic literature review in Malaysian higher education. Int. J. Eng. Technol. 2018, 7, 2197-2202. [CrossRef]

20. Ifinedo, P. Applying uses and gratifications theory and social influence processes to understand students' pervasive adoption of social networking sites: Perspectives from the Americas. Int. J. Inf. Manag. 2016, 36, 192-206. [CrossRef]

21. Venkatesh, V.; Morris, M.G.; Davis, G.B.; Davis, F.D. User acceptance of information technology: Toward a unified view. Mis $Q$. 2003, 27, 425-478. [CrossRef]

22. Lee, M.C. Explaining and predicting users' continuance intention toward elearning: An extension of the expectation-confirmation model. Comput. Educ. 2010, 54, 506-516. [CrossRef]

23. Davis, F.D.; Bagozzi, R.P.; Warshaw, P.R. User acceptance of computer technology: A comparison of two theoretical models. Manag. Sci. 1989, 35, 982-1003. [CrossRef]

24. Alenazy, W.M.; Al-Rahmi, W.M.; Khan, M.S. Validation of TAM model on social media use for collaborative learning to enhance collaborative authoring. IEEE Access 2019, 7, 71550-71562. [CrossRef]

25. Al-Maatouk, Q.; Othman, M.S.; Aldraiweesh, A.; Alturki, U.; Al-Rahmi, W.M.; Aljeraiwi, A.A. Task-technology fit and technology acceptance model application to structure and evaluate the adoption of social media in academia. IEEE Access 2020, 8, 78427-78440. [CrossRef]

26. Alraimi, K.M.; Zo, H.J.; Ciganek, A.P. Understanding the MOOCs continuance: The role of openness and reputation. Comput. Educ. 2015, 80, 28-38. [CrossRef]

27. Alalwan, N.; Al-Rahmi, W.M.; Alfarraj, O.; Alzahrani, A.; Yahaya, N.; Al-Rahmi, A.M. Integrated three theories to develop a model of factors affecting students' academic performance in higher education. IEEE Access 2019, 7, 98725-98742. [CrossRef]

28. Hong, J.Y.; Suh, E.H.; Kim, S.J. Context-aware systems: A literature review and classification. Expert Syst. Appl. 2009, 36, 8509-8522. [CrossRef]

29. Al-Rahmi, W.M.; Yahaya, N.; Aldraiweesh, A.A.; Alturki, U.; Alamri, M.M.; Saud, M.S.B.; Kamin, Y.B.; Aljeraiwi, A.A. Big data adoption and knowledge management sharing: An empirical investigation on their adoption and sustainability as a purpose of education. IEEE Access 2019, 7, 47245-47258. [CrossRef]

30. Al-Rahmi, W.; Aldraiweesh, A.; Yahaya, N.; Kamin, Y.B.; Zeki, A.M. Massive open online courses (MOOCs): Data on higher education. Data Brief 2019, 22, 118-125. [CrossRef] 
31. Alyoussef, I.Y.; Alamri, M.M.; Al-Rahmi, W.M. Social media use (SMU) for teaching and learning in Saudi Arabia. Int. J. Recent Technol. Eng. 2019, 8, 942-946.

32. Mulik, S.; Yajnik, N.; Godse, M. Determinants of acceptance of massive open online courses. In Proceedings of the 2016 IEEE Eighth International Conference on Technology for Education (T4E), Mumbai, India, 2-4 December 2016; pp. $124-127$.

33. Deng, J. Research on Higher Vocational Students' Acceptance and Use of MOOC in Web Software Development Course. Boletín Técnico 2017, 55, 689-695, ISSN 0376-723X.

34. Venkatesh, V.; Thong, J.Y.; Xu, X. Consumer acceptance and use of information technology: Extending the unified theory of acceptance and use of technology. Mis Q. 2012, 36, 157-178. [CrossRef]

35. Al-Rahmi, W.M.; Alzahrani, A.I.; Yahaya, N.; Alalwan, N.; Kamin, Y.B. Digital communication: Information and communication technology (ICT) usage for education sustainability. Sustainability 2020, 12, 5052. [CrossRef]

36. Aljukhadar, M.; Senecal, S.; Nantel, J. Is more always better? Investigating the task-technology fit theory in an online user context. Inf. Manag. 2014, 51, 391-397. [CrossRef]

37. Alamri, M.M.; Almaiah, M.A.; Al-Rahmi, W.M. The Role of Compatibility and Task-Technology Fit (TTF): On Social Networking Applications (SNAs) Usage as Sustainability in Higher Education. IEEE Access 2020, 8, 161668-161681. [CrossRef]

38. Moafa, F.A.; Ahmad, K.; Al-Rahmi, W.M.; Yahaya, N.; Kamin, Y.B.; Alamri, M.M. Develop a model to measure the ethical effects of students through social media use. IEEE Access 2018, 6, 56685-56699. [CrossRef]

39. Alario-Hoyos, C.; Perez-Sanagustin, M.; Delgado-Kloos, C.; Parada, H.A.; Munoz-Organero, M. Delving into participants' profiles and use of social tools in MOOCs. IEEE Trans. Learn. Technol. 2014, 7, 260-266. [CrossRef]

40. Chiappe-Laverde, A.; Hine, N.; Martinez-Silva, J.A. Literature and practice: A critical review of MOOCs. Comunicar 2015, 44, 9-18. [CrossRef]

41. Zhou, M.M. Chinese university students' acceptance of MOOCs: A self determination perspective. Comput. Educ. 2016, 92-93, 194-203. [CrossRef]

42. Al-Rahmi, W.M.; Othman, M.S.; Yusuf, L.M. Exploring the factors that affect student satisfaction through using e-learning in Malaysian higher education institutions. Mediterr. J. Soc. Sci. 2015, 6, 299. [CrossRef]

43. Abuhassna, H.; Al-Rahmi, W.M.; Yahya, N.; Zakaria, M.A.Z.M.; Kosnin, A.B.M.; Darwish, M. Development of a new model on utilizing online learning platforms to improve students' academic achievements and satisfaction. Int. J. Educ. Technol. High. Educ. 2020, 17, 1-23. [CrossRef]

44. Moore, J.C. A Synthesis of Sloan-C Effective Practices, December 2011. J. Asynchronous Learn. Netw. 2012, 16, 91-115. [CrossRef]

45. Kim, H.B.; Kim, T.T.; Shin, S.W. Modeling roles of subjective norms and eTrust in customers' acceptance of airline B2C eCommerce websites. Tour. Manag. 2009, 30, 266-277. [CrossRef]

46. Al-Rahmi, W.M.; Yahaya, N.; Aldraiweesh, A.A.; Alamri, M.M.; Aljarboa, N.A.; Alturki, U.; Aljeraiwi, A.A. Integrating technology acceptance model with innovation diffusion theory: An empirical investigation on students' intention to use E-learning systems. IEEE Access 2019, 7, 26797-26809. [CrossRef]

47. Culibrk, L.; Croft, C.A.; Tebbutt, S.J. Systems biology approaches for host-fungal interactions: An expanding multi-omics frontier. Omics J. Integr. Biol. 2016, 20, 127-138. [CrossRef] [PubMed]

48. Schuwirth, L.W.; van der Vleuten, C.P. A plea for new psychometric models in educational assessment. Med. Educ. 2006, 40, 296-300. [CrossRef] [PubMed]

49. Alamri, M.M.; Almaiah, M.A.; Al-Rahmi, W.M. Social media applications affecting Students' academic performance: A model developed for sustainability in higher education. Sustainability 2020, 12, 6471. [CrossRef]

50. Ye, C.; Biswas, G. Early prediction of student dropout and performance in MOOCs using higher granularity temporal information. J. Learn. Anal. 2014, 1, 169-172. [CrossRef]

51. Rueda, L.; Benitez, J.; Braojos, J. From traditional education technologies to student satisfaction in Management education: A theory of the role of social media applications. Inf. Manag. 2017, 54, 1059-1071. [CrossRef]

52. Sekaran, U.; Bougie, R. Research Methods for Business: A Skill Building Approach; John Wiley \& Sons: Hoboken, NJ, USA, 2016.

53. Hair, J.F.; Risher, J.; Sarstedt, M.; Ringle, C. When to use and how to report the results of PLS-SEM. Eur. Bus. Rev. 2019, 31, 2-24. [CrossRef]

54. Wu, B.; Zhang, C.Y. Empirical study on continuance intentions towards ELearning 2.0 systems. Behav. Inf. Technol. 2014, 33, 1027-1038. [CrossRef]

55. Kim, T.; Suh, Y.K.; Lee, G.; Choi, B.G. Modelling roles of task-technology fit and self-efficacy in hotel employees' usage behaviours of hotel information systems. Int. J. Tour. Res. 2010, 12, 709-725. [CrossRef]

56. Sun, P.C.; Tsai, R.J.; Finger, G.; Chen, Y.Y.; Yeh, D. What drives a successful elearning? An empirical investigation of the critical factors influencing learner satisfaction. Comput. Educ. 2008, 50, 1183-1202. [CrossRef]

57. Fianu, E.; Blewett, C.; Ampong, G.O. Toward the development of a model of student usage of MOOCs. Educ. Train. 2020, 62, 521-541. [CrossRef]

58. Tseng, T.H.; Lin, S.; Wang, Y.S.; Liu, H.X. Investigating teachers' adoption of MOOCs: The perspective of UTAUT2. Interact. Learn. Environ. 2019, 1-16. [CrossRef]

59. Joo, Y.J.; So, H.J.; Kim, N.H. Examination of relationships among students' self-determination, technology acceptance, satisfaction, and continuance intention to use K-MOOCs. Comput. Educ. 2018, 122, 260-272. [CrossRef] 
60. Aharony, N.; Bar-Ilan, J. Students' perceptions on MOOCs: An exploratory study. Interdiscip. J. E-Ski. Life Long Learn. 2016, 12, 145-162. [CrossRef]

61. Almaiah, M.A.; Alamri, M.M.; Al-Rahmi, W.M. Analysis the effect of different factors on the development of Mobile learning applications at different stages of usage. IEEE Access 2019, 8, 16139-16154. [CrossRef]

62. Arpaci, I.; Al-Emran, M.; Al-Sharafi, M.A. The impact of knowledge management practices on the acceptance of Massive Open Online Courses (MOOCs) by engineering students: A cross-cultural comparison. Telemat. Inf. 2020, 54, 101468. [CrossRef]

63. Al-Adwan, A.S. Investigating the drivers and barriers to MOOCs adoption: The perspective of TAM. Educ. Inf. Technol. 2020, 25, 5771-5795. [CrossRef]

64. Kim, R.; Song, H.D. Examining the Influence of Teaching Presence and Task-Technology Fit on Continuance Intention to Use MOOCs. Asia-Pac. Educ. Res. 2021, 1-14. [CrossRef]

65. Rahman, N.A.; Adli, N.W.Z.; Raffei, A.M.; Ismail, N.S.N. Factors Determination MOOCs Continuance Intention: A Proposed Conceptual Framework. In IOP Conference Series: Materials Science and Engineering, February 2020; IOP Publishing: Bristol, UK, 2020; Volume 769, p. 012052.

66. Virani, S.R.; Saini, J.R.; Sharma, S. Adoption of massive open online courses (MOOCs) for blended learning: The Indian educators' perspective. Interact. Learn. Environ. 2020, 1-17. [CrossRef]

67. Ing, H.C.; Yahaya, N.; Kumar, L.; Al-Rahmi, W.M. Examining Learners' Interaction Pattern in Asynchronous Text-Based Online Learning. i-Manag. J. Educ. Technol. 2020, 16, 9.

68. Khoa, B.T. The Perceived Enjoyment of the Online Courses in Digital Transformation Age: The Uses-Gratification Theory Approach. In Proceedings of the 2020 Sixth International Conference on e-Learning, Sakheer, Bahrain, 6-7 December 2020; pp. 183-188.

69. Pozón-López, I.; Higueras-Castillo, E.; Muñoz-Leiva, F.; Liébana-Cabanillas, F.J. Perceived user satisfaction and intention to use massive open online courses (MOOCs). J. Comput. High. Educ. 2021, 33, 85-120. [CrossRef]

70. Alhussain, T.; Al-Rahmi, W.M.; Othman, M.S. Students' Perceptions of Social Networks Platforms use in Higher Education: A Qualitative Research. Int. J. Adv. Trends Comput. Sci. Eng. 2020, 9, 2589-2603. [CrossRef]

71. Wan, L.; Xie, S.; Shu, A. Toward an Understanding of University Students' Continued Intention to Use MOOCs: When UTAUT Model Meets TTF Model. Sage Open 2020, 10, 2158244020941858. [CrossRef]

72. Khan, I.U.; Hameed, Z.; Yu, Y.; Islam, T.; Sheikh, Z.; Khan, S.U. Predicting the acceptance of MOOCs in a developing country: Application of task-technology fit model, social motivation, and self-determination theory. Telemat. Inform. 2018, 35, 964-978. [CrossRef]

73. Almaiah, M.A.; Alamri, M.M.; Al-Rahmi, W. Applying the UTAUT model to explain the students' acceptance of mobile learning system in higher education. IEEE Access 2019, 7, 174673-174686. [CrossRef]

74. Hew, K.F.; Hu, X.; Qiao, C.; Tang, Y. What predicts student satisfaction with MOOCs: A gradient boosting trees supervised machine learning and sentiment analysis approach. Comput. Educ. 2020, 145, 103724. [CrossRef]

75. Hanzaki, M.R.; Epp, C.D. The effect of personality and course attributes on academic performance in MOOCs. In European Conference on Technology Enhanced Learning; Springer: Cham, Switzerland, 2018; pp. 497-509.

76. Carannante, M.; Davino, C.; Vistocco, D. Modelling students' performance in MOOCs: A multivariate approach. Stud. High. Educ. 2020, 1-16. [CrossRef]

77. Tan, P.J.B. An empirical study of how the learning attitudes of college students toward English e-tutoring websites affect site sustainability. Sustainability 2019, 11, 1748. [CrossRef]

78. Tan, P.J.B. Applying the UTAUT to understand factors affecting the use of English e-learning websites in Taiwan. Sage Open 2013, 3, 2158244013503837. [CrossRef] 